\title{
THE STRUCTURE AND STEREOCHEMISTRY OF ARTEMIN*
}

\section{antonio G. González, Jaime Bermejo, Horacio Mansilla, Gulllermo M. Massanet, Inmaculada Cabrera, Juan M. Amaro and Antonio Galindo}

Department of Organic Chemistry and Biochemistry, University of La Laguna, Instituto de Productos Naturales, Orgánicos del CSIC, La Laguna, Tenerife, Canary Islands, Spain

(Revised received 14 March 1977)

Key Word Index-Artemisia maritima; Compositae; sesquiterpene lactone; artemin.

Abstract-Artemin was isolated from the aerial part of Artemisia maritima. Its structure and stereochemistry were determined on the basis of chemical transformations and spectral evidence

\section{INTRODUCTION}

As part of our researches into sesquiterpene lactones from the Compositae, especially from the genus Artemisia, we have begun a study of Artemisia maritima L ssp Gallica Willd.

\section{RESULTS AND DISCUSSION}

Following the method described in the Experimental we obtained a crystalline product with an intensely bitter taste, mp 238-240, $\mathrm{C}_{15} \mathrm{H}_{22} \mathrm{O}_{4},[\alpha]_{\mathrm{D}} 167^{\circ}$ (1a). The spectral data indicated a sesquiterpene lactone; thus the IR spectrum showed absorption bands at 3570 (hydroxyl), 1770 ( $\gamma$-lactone), 1650 and $920 \mathrm{~cm}^{-1}$ (methylene double bond). The NMR spectrum showed a broad singlet at $\delta 5,00$ ( 2 protons, corresponding to a methylene double bond), a group of signals centred at $\delta 4.20$ representative of a lactonic proton at C- 6 and a proton geminal to a hydroxyl group; a singlet at $\delta 0.86$ corresponding to an angular methyl and a doublet at $\delta 1.20(J=6 \mathrm{~Hz})$ attributable to a secondary methyl. We propose the relative $\alpha$-configuration for this methyl on the basis of the coupling constant $[1,2]$. On treatment of this product with acetic anhydride, a mono-acetate was formed, $\mathrm{mp} 227-229^{\circ}, \mathrm{C}_{17} \mathrm{H}_{24} \mathrm{O}_{5},[\alpha]_{\mathrm{D}} 146^{\circ}(\mathbf{1 b})$. Its IR spectrum showed that this substance had the same absorptions as the original alcohol, plus the signal at $1720 \mathrm{~cm}^{-1}$ characteristic of an acetate group. The signals typical of secondary and tertiary methyls, as well as those of lactonic proton (doublet at $\delta 4.28, J=11 \mathrm{~Hz}$ ) and of the acetyl group (a singlet at $\delta 2.05$ ), could be observed in the NMR spectrum. The signal of the proton geminal to the secondary hydroxyl showed a paramagnetic shift (under acetylation) of $1.22 \mathrm{ppm}$, appearing as a doublet of doublets at $\delta 5.42$. At low field, a doublet was seen at $\delta 5.05$, attributable to an isolated methylene. The presence of hydroxyl group absorptions in the IR spectrum of the monoacetate (1b) suggested the presence of a tertiary hydroxyl group.

\footnotetext{
* Part 34 in the series 'Chemistry of the Compositae'; for part 33, see González A.G., Arteaga, J. M., Bretón, J. L. and Fraga, B. M. (1977) Phytochemistry 16, 107.
}

The constants of artemin, isolated by Rybalko et al. [3] from Artemisia taurica, are identical to those of our product. The Russian authors give a probable gross structure for artemin (1a) without definitely establishing the position of the secondary hydroxyl group, nor the stereochemistry of the assymetric centres.

With the idea of determining these points, we carried out a more intensive study of the structure and stereochemistry of artemin. Using Grieco's procedure [4], enolization and subsequent phenylselenylization of the lactone, we obtained the phenylselenide (2). The oxidation of this compound (2) with $30 \% \quad \mathrm{H}_{2} \mathrm{O}_{2}$ in $\mathrm{THF} /$ acetic acid gave rise to a selenoxide (3), as intermediate product which suffered a syn-elimination to form product 4 which was identified as tanacetin [5] by comparing its IR and NMR spectra with those of an authentic sample. This allowed us to determine the position and stereochemistry of the secondary and tertiary hydroxyls (1 $\beta$-equatorial, $5 \alpha$-axial, respectively) as well as the disposition of the C-6 and C-7 hydrogen atoms ( $6 \beta$ and $7 \alpha$ axial). $\mathrm{NaBH}_{4}$ reduction of 4 led to product 5 , the $R_{f}$ values of which on TLC with various eluents were identical to those displayed by artemin. This confirmed the $\alpha$-orientation of the C-11 methyl group since this type of reduction is highly stereospecific and always yields the $\alpha$-epimer [6]. From the foregoing data, we deduced tha the artemin isolated in this laboratory from Artemisia maritima is $1 \beta, 5 \alpha$-dihydroxy- $6 \beta, 7 \alpha, \mathrm{H}$-selin4(15)-en-11 $\alpha$-methyl-6,12-olide (5).

On the basis of only spectral evidence, Tarasov et al. [7] gave arsubin the structure that we have established for artemin and they claimed that arsubin and artemin are epimeric at $\mathrm{C}-11$. They determined the $\mathrm{C}-11$ configuration of arsubin by relating it to the downfield shift ( $\Delta \delta=+0.12 \mathrm{ppm}$ ) of the C-6 proton in $\beta$-santonin as compared with $\alpha$-santonin [8]. From the downfield shift $(\Delta \delta=+0.23 \mathrm{ppm})$ of the C-6 protons in acetylarsubin and acetylartemin, they conclude that the $C-11$ methyl group in arsubin and $\beta$-santonin have the same configuration. However, the formula they assign to arsubin $(11 \alpha$-methyl) contradicts this theory, while the the other configuration $(11 \beta$-methyl) would favour their 


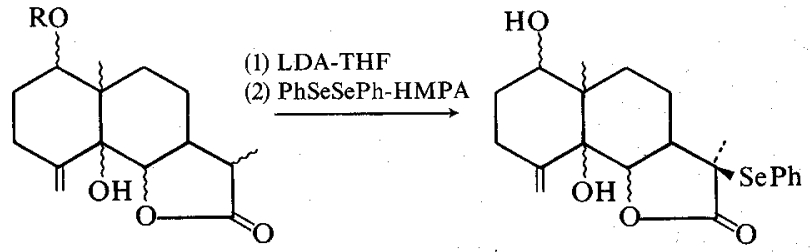

(1)

(a) $\mathrm{R}=\mathrm{H}$ (b) $\mathrm{R}=\mathrm{Ac}$

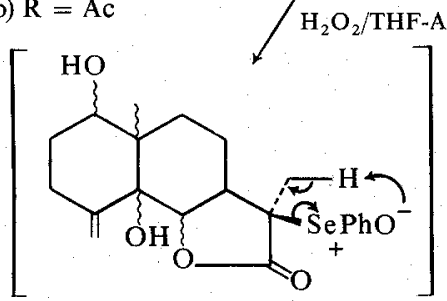

(3)

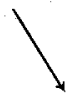

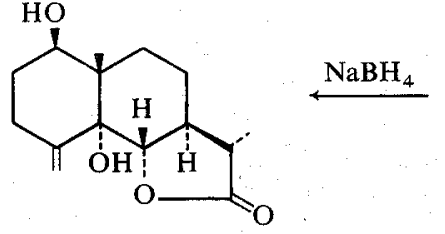

(5)

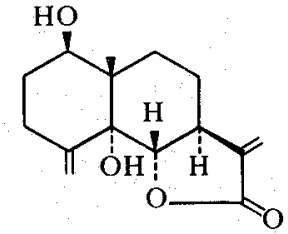

(4)

argument that arsubin and artemin are probably epimeric at C-11.

\section{EXPERIMENTAL}

Mp's are uncorr. Optical activities were measured in $\mathrm{CHCl}_{3}$, UV spectra in EtOH and NMR spectra at $90 \mathrm{MHz}$ in $\mathrm{CDCl}_{3}$ with TMS as internal reference. The standard method referred to below consists of pouring into $\mathrm{H}_{2} \mathrm{O}$, extracting with solvents $\left(\mathrm{CHCl}_{3}\right.$ or EtOAc), washing the extract, drying with dry $\mathrm{Na}_{2} \mathrm{SO}_{4}$, distilling and crystallizing. The aerial part of the plant $(20 \mathrm{~kg})$ was collected at Cabo Corbera (Valencia, Spain) in the months May-July, triturated and exhaustively extracted with hot EtOH. The EtOH extract was concd in vacuo, yielding a syrupy liquid with an intensely bitter taste. This was dissolved in 11 . of hot EtOH with 21. of boiling $\mathrm{H}_{2} \mathrm{O}$ containing $\mathrm{Pb}(\mathrm{OAc})_{4}$ $(12 \mathrm{~g})$. This was left for $24 \mathrm{hr}$, then filtered, most of the alcohol being eliminated. The resulting extract was treated in the normal fashion giving an oily liquid $(650 \mathrm{~g})$ which was chromatographed on $\mathrm{Si}$ gel $(6 \mathrm{~kg}) 0.2-0.5 \mathrm{~mm}$. The column was eluted with $\mathrm{C}_{6} \mathrm{H}_{6}$ and mixtures of $\mathrm{C}_{6} \mathrm{H}_{6}$ EtOAc.

Artemin. The product obtained in $0.4 \%$ yield from $\mathrm{C}_{6} \mathrm{H}_{6}-$ EtOAc elution crystallized in petrol-EtOAc: mp 238-240 ; MS m/e: $266\left(\mathrm{M}^{+}\right) ;[\alpha]_{\mathrm{D}} 167^{\circ}(\mathrm{ca} 0.5)$; IR $v_{\text {max }} \mathrm{cm}^{-1}: 3570,1770$, 1650 and $920 ; \mathrm{NMR}: \delta 5.00\left(2 \mathrm{H}, \mathrm{s}, \mathrm{C}-4=\mathrm{CH}_{2}\right), 4.20(2 \mathrm{H}, \mathrm{C}-6$ and $\mathrm{C}-1), 0.86(3 \mathrm{H}, s, \mathrm{C}-10 \mathrm{Me})$ and $1.20(3 \mathrm{H}, d, J=6 \mathrm{~Hz}, \mathrm{C}-11 \mathrm{ME})$. (Found: C, 67.55; H, 8.08. Calc for $\mathrm{C}_{15} \mathrm{H}_{22} \mathrm{O}_{4}: \mathrm{C}, 67.65 ; \mathrm{H}$, $8.33 \%$ ).

Monoacetylartemin. Ca $55 \mathrm{mg}$ of the alcohol was dissolved in $\mathrm{Py}$ and $\mathrm{Ac}_{2} \mathrm{O}(2 \mathrm{ml})$ was added. The mixture was left for $12 \mathrm{hr}$ and recovered in the normal way. The monoacetate thus obtained crystallized in EtOAc-petrol: $\mathrm{mp} 227-229^{\circ}$; $\mathrm{MS} ; \mathrm{m} / \mathrm{e}$ : $308\left(\mathrm{M}^{+}\right) ;[\alpha]_{\mathrm{D}} 146^{\circ}$ ( ca 0.23); IR $v_{\max } \mathrm{cm}^{-1}: 3570,1770,1720$, 1650 and 920; NMR: $\delta 1.00(3 \mathrm{H}, s, \mathrm{C}-10 \mathrm{Me}), 1.25(3 \mathrm{H}, d$, $J=7 \mathrm{~Hz}, \mathrm{C}-11 M e), 4.28(1 \mathrm{H}, d, J=11 \mathrm{~Hz}, \mathrm{C}-6), 2.05(3 \mathrm{H}, s$, OAc), $5.05\left(2 \mathrm{H}, d, J=4.5 \mathrm{~Hz}, \mathrm{C}-4=\mathrm{CH}_{2}\right)$ and $5.42(1 \mathrm{H}, d d$, C-1). (Found: $\mathrm{C}, 65.97 ; \mathrm{H}, 7.95$. Calc for $\mathrm{C}_{17} \mathrm{H}_{24} \mathrm{O}_{5}: \mathrm{C}, 66.21$; $\mathrm{H}, 7.84 \%$ ).

Phenylselenylization of artemin. $(i-\mathrm{Pr}){ }_{2} \mathrm{NH}(0.09 \mathrm{ml}), \mathrm{BuLi}$ $(0.4 \mathrm{ml} 2 \mathrm{~m}$ in hexane) and dry THF $(0.4 \mathrm{ml})$ were placed under dry Ar atmosphere and then cooled to $-78^{\circ}$. The lactone (133 $\mathrm{mg}$ ) was added slowly over $1 \mathrm{hr}$ and then stirred for $20 \mathrm{~min}$ at $-78^{\circ}$. Once the enolate had formed, diphenyldiselenide (188.5 $\mathrm{mg})$ dissolved in dry THF $(0.5 \mathrm{ml})$ containing HMPA $(0.105 \mathrm{mg})$ was added rapidly in drops. After $40 \mathrm{~min}$ at $-78^{\circ}$, the temp. was raised to $-40^{\circ}$ and the mixture stirred for $1.5 \mathrm{hr}$ at that temp. The reaction was halted by the addition of $10 \% \mathrm{HCl}$. The resulting phenylselenide was recovered as normal, giving a yellow oil which could not be crystallized. MS m/e: $422\left(\mathrm{M}^{+}\right)\left(\mathrm{C}_{15^{-}}\right.$ $\left.\mathrm{H}_{2,} \mathrm{O}_{4} \mathrm{PhSe}\right)$; NMR: $\delta 1.55(3 \mathrm{H}, s, \mathrm{C}-11 \mathrm{Me}), 0.86(3 \mathrm{H}, \mathrm{s}, \mathrm{C}-10$ Me), $4.92\left(2 \mathrm{H}, d, J=12 \mathrm{~Hz}, \mathrm{C}-4=\mathrm{CH}_{2}\right)$ and $7.3-7.7(5 \mathrm{H}, m$, $-\mathrm{C}_{6} \underline{\mathrm{H}}_{5}$ ).

11-methylenation. Phenylselenide $(15 \mathrm{mg})$ in THF $(1 \mathrm{ml})$ containing HOAc $(0.01 \mathrm{ml})$ was cooled to $0^{\circ}$ and $30 \% \mathrm{H}_{2} \mathrm{O}_{2}$ soln $(0.04 \mathrm{ml})$ was added. The mixture was stirred for $30 \mathrm{~min}$ at $0^{\circ}$, poured into a cold $\mathrm{NaHCO}_{3}$ soln, then recovered by the standard process. Crystallization in EtOAc-petrol; mp 206-207 ; IR $v_{\max } \mathrm{cm}^{-1}: 3570,1770,1650$ and $920 ; \mathrm{NMR}: \delta 6.12$ and 5.45 ( $1 \mathrm{H}$ each, $\left.d d, J=3.5 \mathrm{~Hz}, \mathrm{C}-11=\mathrm{CH}_{2}\right), 5.05\left(2 \mathrm{H}, s, \mathrm{C}-4=\mathrm{CH}_{2}\right)$ $4.30(1 \mathrm{H}, d, J=11 \mathrm{~Hz}, \mathrm{C}-6), 4.15(1 \mathrm{H}, m, \mathrm{C}-1)$ and $0.90(3 \mathrm{H}, s$, $\mathrm{C}-10 \mathrm{Me})$.

Reduction with $\mathrm{NaBH}_{4}$. About $10 \mathrm{mg}$ of the above product was dissolved in $\mathrm{MeOH}(8 \mathrm{ml}), \mathrm{NaBH}_{4}(60 \mathrm{mg})$ added, and the mixture was stirred at $0^{\circ}$ for $10 \mathrm{~min}$. The $\mathrm{MeOH}$ was then eliminated and the residue acidified with $5 \% \mathrm{HCl}$; after the usual work-up, an oily substance was obtained. The $R_{f}$ of artemin and this compound were identical in $\mathrm{C}_{6} \mathrm{H}_{6}-\mathrm{EtOAc}$ (7:3), EtOAc-petrol $(1: 1)$ and $\mathrm{Me}_{2} \mathrm{CO}-(i-\mathrm{Pr})_{2} \mathrm{O}(7: 3)$.

Acknowledgements-We are indebted to Prof Herout of Prague for the IR and NMR spectra of tanacetin.

\section{REFERENCES}

1. Samek, Z. (1971) Tetrahedron Letters 1709.

2. Samek, Z., Holub, M., Blossyk, E., Drozdz, B. and Herout, V. (1975) Coll. Czech. Chem. Commun. 40, 2676.

3. Tolstykh, L. P., Scheichenko, V. I., Ban'koskii, A. I. and Ryablko, K. S. (1968) Khim. Prir. Soedin 4, 384.

4. Grieco, P. A. and Miyashita, M. (1974) J. Org. Chem. 39, 120.

5. Samek, Z., Holub, M., Graborczyk, H., Drozdz, B. and Herout, V. (1973) Coll. Czech. Chem. Commun. 38, 1804.

6. Corbella A., Gariboldi, P., Jommi, G., Orsini, F. and Ferrari, G. (1974) Phytochemistry 13, 459 and references cited therein.

7. Tarasov, V. A., Kasymov, S. Z. and Sidyakin, G. P. (1973) Khim. Prir. Soedin 9, 676.

8. Pinhey J. T. and Sternhell, S. (1965) Australian J. Chem. 18, 543 . 